\title{
Online Learning Through WhatsApp Group in Improving Learning Motivation in the Era and Post Pandemic COVID -19
}

\author{
Samsul Susilawati ${ }^{1}$, Triyo Supriyatno ${ }^{1}$ \\ ${ }^{1}$ Faculty of Tarbiyah and Teacher Training-Universitas Islam Negeri Maulana Malik Ibrahim
}

\begin{tabular}{l} 
ARTICLE INFO \\
\hline Article History: \\
Received: 11-05-2020 \\
Approved: $23-06-2020$ \\
\hline
\end{tabular}

Key Words:

online learning;

motivation;

COVID-19;

pembelajaran online;

motivasi;

COVID-19

\begin{abstract}
Abstract: The purpose of this study is to find out the online learning process in the middle and post-pandemic Covid-19. This research employed one group pretest-posttest design. The subjects of the study were the fourth-semester students of the MPI Department of the State Islamic University of Maulana Malik Ibrahim Malang in the even semester of the academic year 2019/2020. The sample of this study was 30 students. Data obtained using a questionnaire. The data analysis technique used a paired T-test with an error rate of $5 \%$. With online learning using WhatsApp shows that there is a correlation between the two variables of 0.776 it shows that there is a correlation between the pretest-posttest, the significance was $0.00<0.05$ then $\mathrm{H} 0$ was accepted. It further confirms that there is a significant increase in student learning outcomes before and after using WhatsApp. The results of the analysis and discussion can be concluded that there is an increase in online learning in the era and post-pandemic Covid-19 by using WhatsApp to increase learning motivation.
\end{abstract}

\begin{abstract}
Abstrak: Tujuan dari penelitian ini adalah untuk mengetahui proses pembelajaran online di tengah dan pasca pandemi Covid-19. Penelitian ini menggunakan one group pretestposttest design. Subjek penelitian ini adalah mahasiswa semester empat Jurusan MPI Universitas Islam Negeri Maulana Malik Ibrahim Malang semester genap tahun ajaran 2019/2020. Sampel penelitian ini adalah 30 mahasiswa. Data diperoleh dengan menggunakan kuesioner. Teknik analisis data menggunakan paired T-test dengan tingkat kesalahan 5\%. Pembelajaran online menggunakan whatsapp menunjukkan bahwa terdapat korelasi antara kedua variabel sebesar 0,776 , hal ini menunjukkan bahwa terdapat korelasi antara pretest-posttest dengan signifikansi $0,00<0,05$ maka H0 diterima. Hasil ini semakin menegaskan bahwa ada peningkatan yang signifikan dalam hasil belajar siswa sebelum dan sesudah menggunakan WhatsApp. Hasil analisis dan pembahasan dapat disimpulkan bahwa terdapat peningkatan pembelajaran online di era dan pasca pandemi Covid-19 dengan menggunakan WhatsApp untuk meningkatkan motivasi belajar.
\end{abstract}

\section{Correspondence:}

Samsul Susilawati

Faculty of Tarbiyah and Teacher Training

Universitas Islam Negeri Maulana Malik Ibrahim

Jalan Gajayana 50 Malang

E-mail: susilawati@pips.uin-malang.ac.id

The spread of the coronavirus disease (COVID-19) has affected all elements of global citizenship, including Indonesian society and the academic community within it. COVID-19 has been declared a world pandemic, referring to the WHO decision as stated (Abidin, Rumansyah, \& Arizona, 2020), that the cases spread outside the city of Wuhan and on January 30, 2020, the World Health Organization (WHO) declared the 2019 novel virus outbreak (2019-nCoV) an International Public Health Emergency (PHEIC) outbreak. The outbreak has caused around 64,000 COVID-19 cases in China so far, and with that number it's growing (Mózo, 2017). Major action is needed regarding the policy of learning models, and this pandemic is a major challenge for the education system (Report, 2020). As was done at the Maulana Malik Ibrahim State Islamic University Malang, previously personal instrumentals shifted to the use of online media and distance learning. It is very important to formulate it as an effort to achieve significant learning outcomes in the COVID-19 pandemic. 
This situation requires all citizens to take precautions so that COVID-19 does not spread more widely. Following up on this emergency, the government provided instructions through university policymakers, instructing college transfers by utilizing the internet network. It is considered a solution to breaking the chain of the COVID-19 pandemic, as UNESCO's move to support countries in their efforts to reduce the direct impact of school closures, especially for the more vulnerable and disadvantaged communities, and to facilitate the sustainability of education for all through distance learning (Ross, Ross, Kenneth and Genevois, \& Ross, 2006).

In line with that (Pratama \& Yusro, 2016), stated that online learning is an alternative that can be applied in the era of technology and communication that is growing too high now. Furthermore, the COVID-19 pandemic highlights the need to use online models and applications to achieve learning goals (Amal, 2019). As a result, innovation in learning is needed to maintain the development of world education (Hadi, 2015). Innovation in learning by online platforms is interpreted as updates or changes caused by, among other things, attempts to solve problems faced by a person or group and to solve problems that arise and improve certain situations or certain processes that occur in society (Indaryani \& Suliworo, 2018). A possible learning model, together with the state of the COVID-19 pandemic, is learning through a network system, such as e-learning prepared by universities through campus websites or using online applications (Prajana, 2017). This is an integrated instructional learning design based on a constructivist approach, which is carried out by utilizing online social networks, such as blogs, wikis, sharing photos, sharing videos, instant messages, and social networking sites that can be accessed by students or teachers (Atiah, 2020).

The use of WhatsApp Messenger or familiarly called WA in the international and national world has increased sharply (Tavangarian, Leypold, Nölting, Röser, \& Voigt, 2004). WhatsApp is an Instant Messenger technology such as SMS with internet data assistance with more attractive supporting features (Kongchan, 2008) (Kurniawati, Maolida, \& Anjaniputra, 2018). The WhatsApp Messenger application has the potential to be used as a learning tool. Learning in today's digital era is greatly helped by the presence of the WhatsApp Messenger application. Learning in schools and colleges is one of the objects for the growing use of the WhatsApp Messenger application. The use of the WhatsApp Messenger application has occurred in schools and colleges. The survey shows that $90 \%$ of students, students and lecturers use the WhatsApp Messenger application in their daily life, as well as in learning activities. WhatsApp Messenger has various features that can be used to communicate with the help of internet services, features contained in whatsapp are Gallery for adding photos, Contacts for inserting contacts, Camera for taking pictures, Audio for sending voice messages, Maps for sending various map coordinates, even Document to insert files in the form of documents. All these files can be instantly sent via the free application. These various features certainly make it easier to learn to communicate through online media. Because of this, efforts to increase student learning motivation are the main things that must be considered in the learning process using WhatsApp is needed to encourage students to be motivated and have broad knowledge. Group WhatsApp Messenger is a discussion group service that can accommodate up to 256 participants, a very large number and can be collected in just one application. Its members can share discussions and information online through this virtual space. Development of Learning Resources and Media is one of the courses that can be applied through online learning through the use of WhatsApp.

Since the early 1990s, the concept of online learning has shaped the possibility of blended learning (Gruszczynska, Merchant, \& Pountney, 2013). Since then, online learning has developed in such a way that it integrates with classroom learning. This is understandable considering that someone tends to combine the new knowledge he gets with the knowledge he has previously had. Currently, the study of blended learning has developed rapidly. The simplest form of blended learning, according to (Amal, 2019) is a combination of physical class activities and learning activities supported by online technology, and then develops further in the integration of learning activities, students, and educators. The benefits of blended learning have been revealed in many studies, according to, among others (Dunia, Di, \& Milenial, 2020) in the process of facilitating online and class-based learning, bridging the gap between learning and work, promoting online collaborative learning, suitable for learning in tertiary institutions, the effectiveness of large and diverse groups of students, being able to adapt to all levels of learning and many institutions including universities, schools medium, military and many other sectors.

Blended learning is a revolution in the field of internet technology-based education that can be used for both distance education and learning support. In its implementation, even though both use internet blended learning technology, it does not require learning using only online methods, but the implementation of learning must still be combined with face-to-face methods. The combination of online learning and face to face learning in blended learning is intended to take the advantages of each learning model from both of them. In online learning, of course, software and hardware must be used to support the implementation of online learning as part of blended learning. One form of software that can be used is the Whatsapp application. WhatsApp(Amry, 2014) is a messaging application for smartphones with a basic similarity to BlackBerry Messenger. WhatsApp Messenger is part of social media (Mistar \& Embi, 2016). Social media is an internet-based application that allows each user to share various kinds of content according to the supporting features. WhatsApp Messenger is a popular technology that has the potential to be used as a learning tool, and in whatsApp messenger there is a WhatsApp Group which is able to build a fun learning related to various discussion topics given by the teacher. The existence of whatsApp messenger cannot be separated from the existence of Net Gen or the digital generation which always wants updates on various internet-based technologies. The digital generation tends to learn collaboratively, does not respond well to lecture 
learning methods, wants information that they can receive individually, and always wants a variety of learning materials that can be accessed easily through technological devices.

E-learning is mainly intended to encourage students to be independent at certain times and take responsibility for their learning (Stone \& Logan, 2018). In addition, e-learning will allow students to play a more active role in their learning as it focuses on personalization, which includes the ability to adapt to the skill level of learners and accumulate knowledge resources as mutual support. (Conference, Jamin, \& Mudra, 2019). In addition, students' adaptive attitudes will provide space and flexibility in organizing themselves, which may lead to success and achievement in learning (Pratama \& Yusro, 2016). So far, e-learning studies tend to discuss learning models based on three perspectives. First, research that examines the problem of online learning as a new learning media system encourages more effective application of learning. Online learning media is likely to create more satisfying services for students (Amry, 2014). shared the same thought that online learning involves selecting components that help improve student learning and enable students to engage with content (Boyinbode, Agbonifo, \& Ogundare, 2017).

Research (Amal, 2019) shows that there are four main considerations in designing online learning (1) learning structure, (2) presentation content, (3) collaboration and interaction, and 4) timely feedback. Second, online learning studies to make it easier for students to access learning materials. The level of need for internet use encourages the development of learning materials that are developed based on subjects and leads to the creation of the final product in the form of e-materials (Ross et al., 2006). A study conducted by (Amry, 2014), shows that in online learning, students tend to access learning material in the form of lecture slides, video lectures, joint assignments, and forum messages. Students with different goals, motivations, and preferences can show different behaviors when accessing this material. This difference in behavior can then affect their learning performance. From this research shows that; first, students view learning material related to their classroom lectures (lecture slides and video lectures) longer and more frequently than other learning material. Second, although students spend a lot of time viewing online learning materials, most do not use analytical tools. Third, research that pays attention to the problem that online learning is complementary which combines some of the best aspects of conventional (face-to-face) learning and information technology-based learning and online communication. Therefore, this learning model equips students with knowledge about how to provide practical and realistic opportunities, which are in line with the form of Blended Learning (Amal, 2019). Given the development of technology and communication, online learning trends are increasing day by day, leaving no room for direct discussion. Blended learning is a combination of online and offline learning that supports deep and meaningful learning without leaving the values of traditional higher education institutions (Awada, 2016). This will potentially increase the effectiveness and efficiency of the learning experience (Boyinbode et al., 2017) with advanced technology (Stone \& Logan, 2018).

Of the three trends, it appears that online learning has been structured as a learning medium that combines conventional learning with information and communication technology. This is an urgent need during the COVID-19 pandemic, which affects the islands. For this reason, it is necessary to be prepared as best as possible so that the expected learning outcomes can be achieved. The aim of this paper is to fill the gaps in existing studies that tend to place the development of online learning models as flawless and not held by many teachers. The availability of various aspects of online learning will be able to show significant learning results. Online learning will also be able to realize a learning approach that is based on self-regulated learning, as the times demand that each student be independent and innovate in the learning process.

WhatsApp groups have pedagogical, social and technological benefits. This application provides support in the implementation of online learning. The WhatsApp group allows its users to deliver certain announcements, share ideas and learning resources, and supports online discussions (Amry, 2014). The Whatsapp Messenger application is able to increase student learning motivation, accelerate the occurrence of study groups in building and developing knowledge. And learning with the help of online applications such as WhatsApp Messenger can enhance collaboration in learning, share knowledge and information that is useful in the learning process, and maintain the joy of learning throughout the ages. Participation, Collaboration, and learning fun are additional values for the learning process. The benefits of using the Whatsapp Messenger Group application in learning, namely (1) Whatsapp Messenger Group provides collaborative and collaborative learning facilities online between teachers and students or fellow students both at home and at school, (2) Whatsapp Messenger Group is a free application that is easy to use, (3) Whatsapp Messenger Group can be used to share comments, texts, images, videos, sounds and documents, (4) Whatsapp Messenger Group makes it easy to disseminate announcements and publish their work in groups, (5) Information and knowledge can be easily created and disseminated through various features of the Whatsapp Messenger Group.

The ARCS motivation model can be used as a measurement of learning motivation (Hamdu \& Agustina, 2011). ARCS is a systematic model for designing learning motivation (Ahmad Kholiqul Amin, 2017). Learning motivation is influenced by four factors, namely attention, trust, satisfaction and relevance. The first component is attention which is done to find out whether learning activities using WhatsApp can increase students' curiosity and attention. The second component is relevance which is used to determine whether the activity is relevant to student needs. This model also assesses whether activities instill confidence in students and whether online activities bring satisfaction to students. Student motivation or level of interest can be used as a predictor of student success or learning 
outcomes (Rahayu \& Hartono, 2016). Motivation data with this model can be collected using a questionnaire with a Likert scale from 1 to 4 ( 4 = strongly agree, $3=$ agree, $2=$ disagree, and $1=$ strongly disagree $)$.

Learning outcomes are abilities or competencies possessed by students after gaining learning experiences. Based on Bloom's taxonomy, learning outcomes can be seen in the cognitive, affective, and psychomotor domains. Lee, et al., (Zaman \& Eliyawati, 2010)]. Learning outcomes are important in the learning process because this is an indicator that can be used as a reference to determine student learning progress, providing feedback for improving the learning process in order to achieve predetermined learning objectives (Maunah, 2016). From these learning outcomes, teachers can design advanced learning in accordance with student characteristics.

\section{METHOD}

Online learning is a policy established by the Islamic State University of Maulana Malik Ibrahim Malang (UIN Maulana Malik Ibrahim Malang), as an effort to prevent COVID-19. This online learning model is an effort to break the chain of COVID-19 by implementing social distance lectures and a distance system using the internet network. This type of research is research. One group pretest-posttest design (Gumanti, Yudiar, \& Syahruddin, 2016). The research subjects (Sugiyono, 2012) were the fourth semester students of the MPI FITK Department of the State Islamic University of Maulana Malik Ibrahim Malang, even semester of the 2019/2020 academic year.

This research was conducted with only 1 class and the number of students was randomly selected as many as 30 students. This research consists of two variables (Suliyanto, 2018), namely learning strategies, namely Blended Learning with the use of WhatsApp and student learning outcomes, namely learning motivation. The independent variable is the learning strategy, in which the learning of the Development of Learning Resources and Media for Integration of Media and Learning Technology, using WhatsApp is an active variable, namely the manipulated variable that will be developed and want to know its effectiveness for learning. and the dependent variable is the learning outcomes of fourth semester students of MPI Department, Maulana Malik Ibrahim State Islamic University, Malang. Even semester of the 2019/2020 academic year is learning motivation for Learning Resources and Media Development. Motivation can serve as a driving force for the achievement of student learning outcomes. The experimental method used is the use of whatsapp learning. When learning begins, students are first given a pretest to determine the extent of students' initial knowledge of the material of Media Integration and Learning Technology. After the pretest, the lecturer asked for help from one of the students to write down the cellphone numbers of his friends so that they could create a WhatsApp group, then the students were divided into 6 groups, each consisting of 5 people. The function of the whatsapp group is to share learning information. Development of learning resources and media in the material of Media Integration and Learning Technology. After learning is complete, students are given a posttest in the form of questions to see student learning outcomes on the material of Media Integration and Learning Technology. and Students provide a questionnaire in the form of a learning motivation questionnaire to see student learning motivation on the material of Media Integration and Learning Technology. The questionnaire used is the Likert scale method which consists of 5 statements with the category of choice, Strongly Agree (SS), Agree (S), Disagree (TS), Strongly Disagree (STS).

\section{RESULT AND DISCUSSION}

Based on the results of research conducted on fourth-semester students of the MPI FITK Department of the State Islamic University of Maulana Malik Ibrahim Malang, even semester of the 2019/2020 academic year, to know an increase in the use of WhatsApp in increasing student learning motivation. WhatsApp is part of E-learning by utilizing the internet function in learning activities by making electronic facilities as learning media. Learning outcomes test. The development of learning resources and media before using WhatsApp to increase student learning motivation can be seen in the frequency distribution histogram below. 


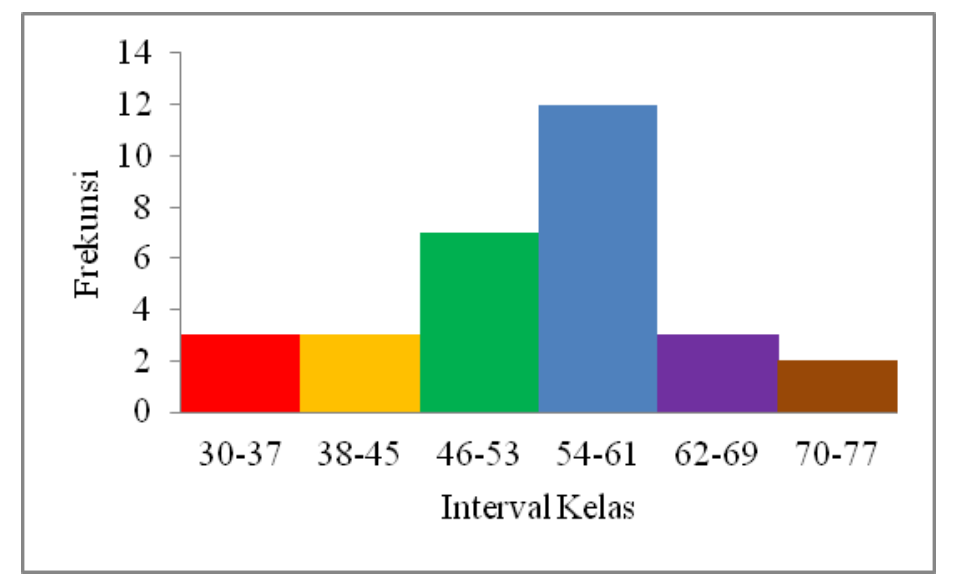

Figure 1. The Histogram of Frequency Distribution of Pretest Score

Figure 1 shows the lowest pretest value of 30 while the highest value is 70 with a standard deviation of 10.53 . While the test of learning outcomes on the Development of Learning Resources and Instructional Media after using WhatsApp in increasing student motivation can be seen in the frequency distribution picture below.

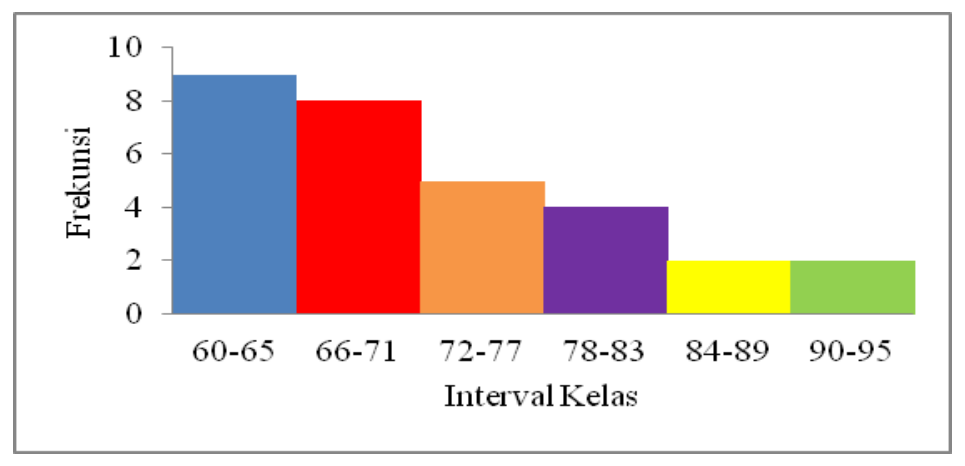

Figure 2. The Histogram of the Posttest Value Frequency Distribution

Figure 2 shows the lowest posttest score of 60 while the highest value is 90 with a standard deviation of 9.14 . The learning outcome test was done by looking at the results of the analysis of the normality test and hypothesis testing. The results of the normality test can be seen in the table 1 .

Table 1. Criteria Scoring the Questionnaire Test

\begin{tabular}{|c|c|c|}
\hline \multirow[b]{2}{*}{$\mathrm{N}$} & $\begin{array}{l}\text { Unstan modernized } \\
\text { Residual } \\
\end{array}$ & \multirow[b]{2}{*}{30} \\
\hline & & \\
\hline \multirow[t]{4}{*}{ Normality } & Mean & .0000000 \\
\hline & Std Deviation & 10.53183 \\
\hline & Absolute & -028 \\
\hline & Positive & .061 \\
\hline Kolmogrov-Smirnov Asymp.Sig.(-2 tailed) & Negative Z Negatif & $\begin{array}{l}.028 \\
.619 \\
.701\end{array}$ \\
\hline
\end{tabular}

a. Lilliefors Significance Correction 
Table 1 shows the results of calculations using SPSS 16.0 that the Kolmogorov-Smirnov Z normality test results of 0.619 are smaller than 0.05 , so the data tested was not normally distributed. The hypothesis test used was a paired t-test. The results of hypothesis testing can be seen from the following tables 2 and 3.

Table 2. Test Hipotesis Paired Samples Statistics

\begin{tabular}{lrrrc}
\multicolumn{2}{c}{ Mean } & N & Std. Deviation & Std. Error Mean \\
\hline Pretest & 53,333330 & 10,53183 & 1,92284 \\
Posttest & 71,833330 & 9,14286 & 1,66925 \\
\hline
\end{tabular}

In table 2, it is known that the pretest average value is 53.33 and the standard deviation value is 10.53 . Meanwhile, the average posttest score was 71.83 and the standard deviation value was 9.14. The standard deviation shows the variation of data on each variable and $\mathrm{N}$ shows a number of data, 30 students.

Table 3. Paired Samples Correlations

\begin{tabular}{llrrr} 
& & N & Correlation & Sig. \\
\hline Pair 1 & Pretest \& Posttest & 30 &, 776 &, 000 \\
\hline
\end{tabular}

Table 3 shows the correlation between the two variables which results in 0.776 , this indicates that there is a correlation between the pretest and posttest. While the significant value of $0.000<0.05$ then $\mathrm{H} 0$ was rejected and $\mathrm{H} 1$ was accepted, this shows that there is a significant increase in student learning outcomes before and after using WhatsApp in increasing student motivation in the Development of Learning Resources and Instructional Subjects.

Blended Learning achievement and motivation are carried out by integrating WhatsApp Messenger as a support for the teaching and learning process, carried out as follows (1) students are formed into five groups in the WhatsApp Messenger application with different material specifications, (2) before class learning is carried out, students are given problems with the Classification of Learning Media material in the form of files sent using the Whats App Messenger application sent to each group, (3) students study the files provided, (4) students are given a learning video about the classification of learning media to increase knowledge and enthusiasm for learning through the WhatsApp Messenger application, (5) classroom learning process presented by the Resistors and Capacitors group,and (6) students work on the test to find out the achievement of learning outcomes.

The data description shows that the learning outcomes value of Learning Resources and Learning Media Development on Media Integration and Learning Technology material before using WhatsApp in increasing student learning motivation shows an average value of 53.33, while the average score of learning outcomes after using WhatsApp in increasing learning motivation students showed a fairly high average score of 71.83. The impact of using WhatsApp in increasing student motivation in Learning Resource Development and Learning Media lessons is very influential on students, students have a very large participation involvement during the teaching and learning process because students are more active and participate so that it can improve student learning outcomes. Students are free to communicate, discuss, and ask questions with educators at any time if they have problems using the Whats App application. According to Johnson et al (2014) discussion forums that exist on various platforms. Based on teaching and learning activities with Blended Learning through WhatsApp Messenger Group shows an increase in student motivation in learning. The reality that occurs in students shows that most of them are only intended for telephone, SMS, and chat. Not much has been used for the use of learning in education. The challenge is that there is not much use of social media to improve the quality of learning. Evrim Baran (2014) states that Blended Learning through the WhatsApp Messenger Group is an attractive learning tool for improving the quality of education. The results showed an increase in student learning motivation after learning by integrating with Blended Learning through the WhatsApp Messenger Group via mobile learning. Besides, the pattern of using social media which is only for entertainment has slightly shifted towards learning. From educators, it is very helpful in controlling, motivating, and facilitating functions.

The questionnaire test carried out during the implementation of learning activities uses WhatsApp which aims to increase student learning motivation. The results obtained by the lift test consisting of 27 questions obtained an average value of $80.31 \%$ included in the category of strongly agree. that there is a significant increase in student learning outcomes after the use of Blended Learning through the WhatsApp Group in increasing learning motivation in and after the COVID-19 pandemic Students in the Learning Source and Media Development Course. Distance learning with Blended Learning through the WhatsApp Messenger Group must be used as best as possible by educators and students. This forum provides online students the opportunity to collaborate and 
work together to build knowledge. Researchers in the field of collaborative and cooperative learning consider discussion forums to be an effective tool for learning. By using mobile devices, mobile learning programs are expected to be more easily accessible and utilized. Amry (2014) states that compared to conventional learning, M-learning allows more opportunities for ad hoc collaboration and informal interaction among learners. Blended Learning integrated with WhatsApp Messenger provides benefits to students, including: (1) Information and knowledge are quickly transferable, (2) the ease of creating discussion forums so that social media becomes a positive means of learning, (3) facilitating seamless collaboration between educators and students, (4) the application is free and easy to use.

\section{CONCLUSION}

Based on the research conducted, it was concluded that there was a significant increase in student learning outcomes through blended learning with the use of WhatsApp in increasing learning motivation in and after the COVID-19 pandemic for students in the Learning Resources and Media Development Course. Interestingly, this study found online learning using WhatsApp Group to be the most effective in and after the COVID-19 pandemic. WhatsApp is easy, simple, and doesn't require a large data credit. Through the WhatsApp Messenger platform, learning takes place optimally because students and lecturers can communicate and share PowerPoint files, Microsoft Word files, JPG files, Voice Notes, Videos, and other learning resource links. This study recommends that other researchers uncover solutions to obstacles experienced by students in online learning and the development of other media for implementing effective online lectures. A more critical and complete study or a study on the application of online learning using other models, of course, will further enrich the science of online learning. In the application of learning activities and the selection of learning media, you should still adjust the environmental context in learning. Not imposing certain activities and methods is a wise step in presenting learning experiences for students. This is because there is no single method that can be used for all conditions.

\section{REFERENCES}

Abidin, Z., Rumansyah, \& Arizona, K. (2020). Pembelajaran Online Berbasis Proyek Salah Satu Solusi Kegiatan Belajar Mengajar di Tengah Pandemi Covid-19. Jurnal Ilmiah Profesi Pendidikan, 5(1), 64-70. https://doi.org/10.29303/JIPP.V5I1.111

Ahmad Kholiqul Amin. (2017). Kajian Konseptual Model Pembelajaran Blended Learning berbasis Web untuk Meningkatkan Hasil Belajar dan Motivasi Belajar. Jurnal Pendidikan Edutama, 4(2).

Allwood, C. M. (2012). The Distinction Between Qualitative and Quantitative Research Methods is Problematic. Quality and Quantity, 46(5), 1417-1429. https://doi.org/10.1007/s11135-011-9455-8

Amal, B. K. (2019). Pembelajaran Blended Learning melalui Whatsapp Group (WAG). Prosiding Seminar Nasional Fakultas Ilmu Sosial Universitas Negeri Medan, 2019, Universitas Negeri Medan, 3, 700-702.

Amry, A. B. (2014). The impact of WhatApp Mobile Social Learning on the Achievement and Attitudes of Female Students Compared with Face to Face Learning in the Classroom. European Scientific Journal, 10(22), 116-136.

Atiah, N. (2020). Pembelajaran Era Disruptif Menuju Masyarakat 5.0. Prosiding Seminar Nasional Pendidikan Program Pascasarjana Universitas PGRI Palembang 10 Januari 2020, 605-617.

Awada, G. (2016). Effect of Whatsapp on Critique Writing Proficiency and Perceptions Toward Learning. Cogent Education, 3(1), 1-25. https://doi.org/10.1080/2331186X.2016.1264173

Boyinbode, O. K., Agbonifo, O. C., \& Ogundare, A. (2017). Supporting Mobile Learning with WhatsApp based on Media Richness. Circulation in Computer Science, 2(3), 37-46. https://doi.org/10.22632/ccs-2017-251-89

Conference, B. I., Jamin, A., \& Mudra, H. (2019). Curriculum Development in Islamic Higher Education : Strengthening Characters of. (2001), 49-56.

Gruszczynska, A., Merchant, G., \& Pountney, R. (2013). "Digital Futures in Teacher Education”: Exploring Open Approaches Towards Digital Literacy. Electronic Journal of E-Learning, 11(3), 193-206.

Gumanti, A., Yudiar, ., \& Syahruddin. (2016). Metode Penelitian Pendidikan. Jakarta: Mitra Wacana Merdeka.

Hadi, B. (2015). Pengembangan ICT dalam Pembelajaran Pengembangan ICT dalam Pembelajaran. Pengembangan ICT Dalam Pembelajaran, (November), 36-44.

Hamdu, G., \& Agustina, L. (2011). Pengaruh Motivasi Belajar Siswa terhadap Pestasi Belajar IPA di Sekolah Dasar (Studi Kasus terhadap Siswa Kelas IV SDN Tarumanagara Kecamatan Tawang Kota Tasikmalaya). Jurnal Penelitian Pendidikan, 12(1), $81-86$.

Indaryani, E., \& Suliworo, D. (2018). Dampak Pemanfaatan WhatsApp dalam Meningkatkan Motivasi Belajar Siswa pada Pelajaran Fisika. Prosiding Seminar Nasional Quantum, 25, 25-31.

Kongchan, C. (2008). How a Non-Digital-Native Teacher Makes Use of Edmodo. Internacional Conference "ICT for Language Learning." 
Kurniawati, N., Maolida, E. H., \& Anjaniputra, A. G. (2018). The Praxis of Digital Literacy in the EFL Classroom: DigitalImmigrant vs digital-native teacher. Indonesian Journal of Applied Linguistics, 8(1), 28 -37. https://doi.org/10.17509/ijal.v8i1.11459

Maunah, B. (2016). Implementasi Pendidikan Karakter Dalam Pembentukan Kepribadian Holistik Siswa. Jurnal Pendidikan Karakter, (1), 90-101. https://doi.org/10.21831/jpk.v0i1.8615

Mistar, I., \& Embi, M. A. (2016). Students' Perception on the Use of Whatsapp As a Learning Tool in ESL Classroom. Journal of Education and Social Sciences, 4, 96-104.

Mózo, B. S. (2017). Implementasi Zoom, Google Classroom, dan Whatsapp Group Dalam Mendukung Pembelajaran Daring (Online) Pada Matakuliah Bahasa Inggris Lanjut. Journal of Chemical Information and Modeling, 53(9), 1689-1699. https://doi.org/10.1017/CBO9781107415324.004

Prajana, A. (2017). Pemanfaatan Aplikasi Whatsapp untuk Media Pembelajaran Dalam Lingkungan UIN Ar-Raniry Banda Aceh. Cyberspace: Jurnal Pendidikan Teknologi Informasi, 1(2), 122. https://doi.org/10.22373/cs.v1i2.1980

Pratama, H., \& Yusro, A. C. (2016). Implementasi WhatsApp Mobile Learning untuk Meningkatkan Hasil Belajar Mahasiswa Pokok Bahasan Pengenalan Komponen Elektronika. Jurnal Pendidikan Fisika dan Keilmuan (JPFK), 2 (2), 65. https://doi.org/10.25273/jpfk.v2i2.696

Rahayu, E., \& Hartono, H. (2016). Keefektifan Model PBL dan PjBL Ditinjau dari Prestasi, Kemampuan Berpikir Kritis, dan Motivasi Belajar Matematika Siswa SMP. PYTHAGORAS: Jurnal Pendidikan Matematika, 11(1), 1. https://doi.org/10.21831/pg.v11i1.9629

Report, M. W. (2020). Severe Outcomes Among Patients with Coronavirus Disease 2019 (COVID-19) — United States, February 12-March 16, 2020. 2020;69:343-346. DOI: http://dx.doi.org/10.15585/mmwr.mm6912e2. MMWR Morb Mortal Wkly Rep, 69(12), 343-346. https://doi.org/10.15585/mmwr.mm6912e2

Ross, K. N., Ross, Kenneth and Genevois, I., \& Ross, K. N. (2006). Cross-National Studies of the Quality of Education : Planning their Design and Managing their Impact. https://doi.org/10.4324/9780203882146

Stone, S., \& Logan, A. (2018). Exploring Students' Use of the Social Networking Site WhatsApp to Foster Connectedness in the Online Learning Experience. Irish Journal of Technology Enhanced Learning, 3(1), 42-55. https://doi.org/10.22554/ijtel.v3i1.28

Sugiyono. (2012). Metode Penelitian Kuantitatif, Kualitatif dan R \& D. Bandung: Alfabeta.

Suliyanto. (2018). Pelatihan Metode Pelatihan Kuantitatif. Journal of Chemical Information and Modeling, 5(2), $223-232$. https://doi.org/10.1017/CBO9781107415324.004

Tavangarian, D., Leypold, M. E., Nölting, K., Röser, M., \& Voigt, D. (2004). Is e-Learning the Solution for Individual Learning? Electronic Journal of E-Learning, 2(2), 273-280.

Zaman, B., \& Eliyawati, C. (2010). Bahan Ajar PPG Media Pembelajaran Anak Usia Dini. Fakultas Ilmu Pendidikan Universitas Indonesia. 